\title{
Sustainable Architectural Design in Indonesia: Responding the Current Environmental Challenges
}

\author{
Gunawan Tanuwidjaja ${ }^{1}$ and Lo Leonardo ${ }^{2}$ \\ ${ }^{1}$ Lecturer of Department of Architecture, Petra Christian University, Indonesia \\ ${ }^{2}$ Students of Department of Architecture, Petra Christian University, Indonesia \\ Email address of corresponding author: gunteitb@yahoo.com, gunte@peter.petra.ac.id
}

\begin{abstract}
The impacts of environmental destructions were felt in Indonesia. The irregular weather patterns, extreme temperatures, as well as floods affected many vulnerable areas in the Country oftentimes. Great numbers of environmental as well as manrelated disasters were recorded such as: 12 earthquakes \& tsunamis (in 2009), 8 volcanic eruptions (in 2008), 631 floods \& landslides (in 2009), and 340 typhoons (in 2009). In total 416 lives were killed and 7,444 houses damaged. And the increasing numbers of environmental disasters was observed.

Further, poverty and weal legal enforcement caused deforestation and severe biodiversity loss. All these challenges required real solution with Indonesian Sustainable Architectural Design Framework, not only the "green rating". And the objective of the research was to find Framework of Sustainable Architectural Design Strategy in Indonesia responding to social economic conditions and addressing these environmental challenges. The framework was urgently needed by Building Construction Sector especially by Indonesian Institute of Architects (IAI). And lastly, it should be sustained with the active participation of all stakeholders.
\end{abstract}

Keywords : Indonesian Sustainable Architectural Design, Environmental Challenges in Indonesia

\section{Introduction}

The impacts of environmental destructions were felt in Indonesia. The irregular weather patterns, extreme temperatures, as well as floods affected many vulnerable areas in the Country oftentimes. Further, natural resource depletion, extinction of plants and animals, loss of wildlife habitats, increasing pollution, and poverty also happened (Miller, 2003). Although possessing abundance natural resource, Indonesia still faced underdevelopment because of $49 \%$ population living in poor condition (World Bank Press Release, 2006 - Making the New Indonesia Work for the Poor). Further, weak legal enforcement and poverty caused deforestation of 64 million ha Indonesian since 1950 was inevitable and the loss of 147 species of mammals, 114 birds, 28 reptiles, 91 fishes and 28 invertebrates. (WRI et all., 2002 - State of the Forest Indonesia; WRI et all., 2000 - Trial by Fire; FAO Global Forest Resources Assessment, 2005).

The objective of the research was to find the Framework of Sustainable Architectural Design Strategy in Indonesia. The framework should address the 
environmental challenges; such as earthquakes, volcanic eruptions, floods, landslides, and tidal waves; as well as social economic issues; such as improving the quality of life, cost effectiveness and efficiency. The framework was urgently needed by Building Construction Sector especially by Indonesian Institute of Architects (IAI) and Universities for implementing Sustainable Development in the Country.

\section{Literature Review}

Located in the Pacific Ring of Fires, Indonesia faced natural environmental challenges, such as earthquakes, tsunamis, volcanic eruptions, typhoons and manrelated environmental challenges, such as floods and landslides. It was recorded that 12 earthquakes \& tsunamis (2009), 8 volcanic eruptions (2008), 631 floods \& landslides (2009), and 340 typhoons (2009). In total, 416 lives were killed and 7,444 houses damaged. And increasing trends of environmental disasters were presented in the Figure 1 to $\quad$ Figure 5 (http://www.bnpb.go.id/ website/index.php?option=com_content\&task=view\&id=2101; http://geospasial.bnpb.go.id/category/peta-tematik/statistik-bencana/; http://dibi.bnpb.go.id/DesInventar/statistics.jsp).

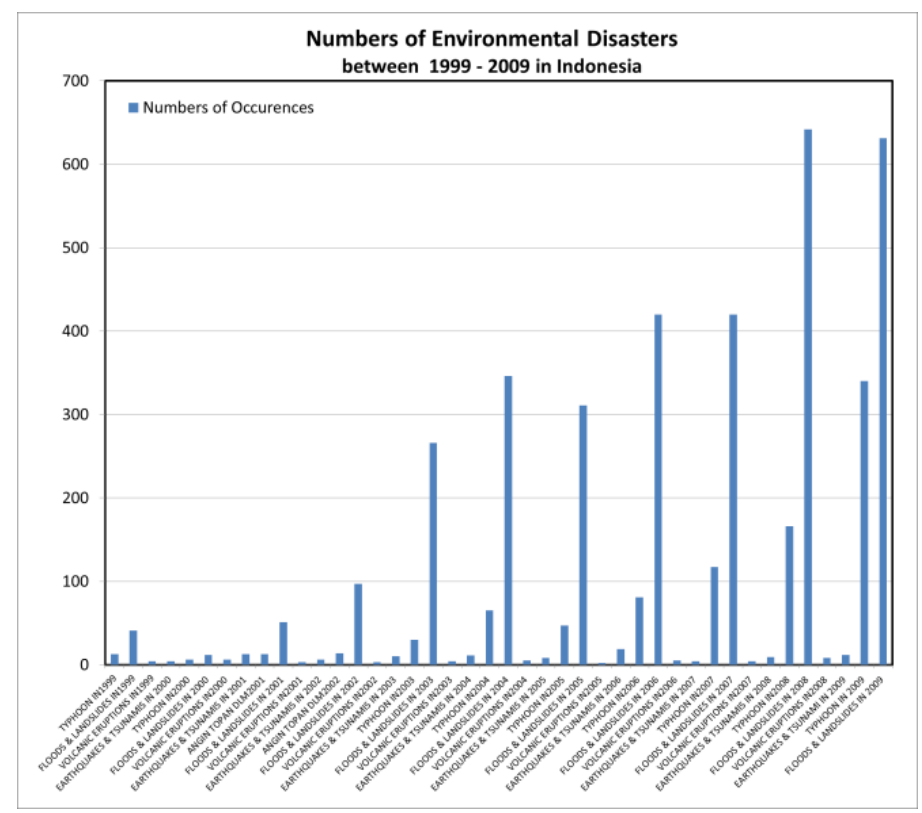

Figure 1. Increase of Environmental Disasters recorded 1999 - 2009

Source: (http://www.bnpb.go.id/website/index.php?option=com_content\&task=view\&id=2101 http://dibi.bnpb.go.id/DesInventar/statistics.jsp) 


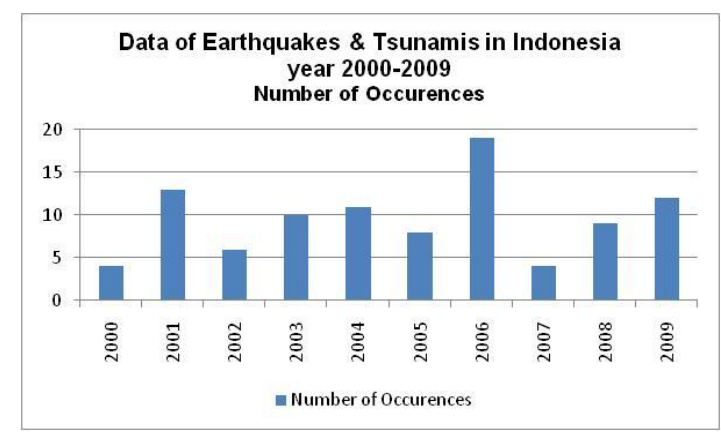

Figure 2. Increase of Earthquakes \& Tsunamis recorded $2000-2009$ Source:

(http://www.bnpb.go.id/website/index.php?option=com_conte nt\&task=view\&id=2101

http://dibi.bnpb.go.id/DesInventar/statistics.jsp)

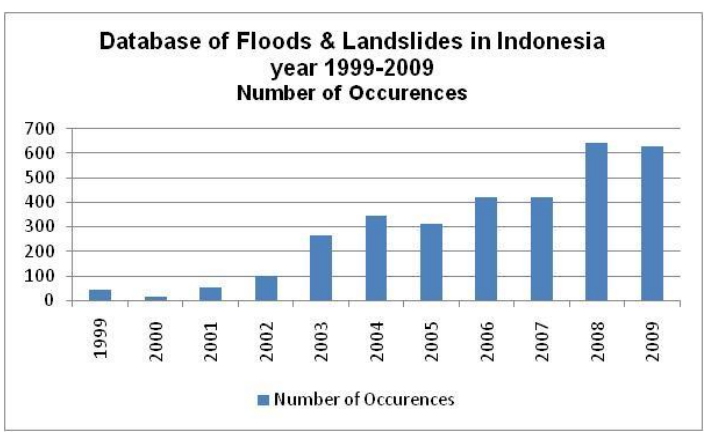

Figure 4. Increase of Floods \& Landslides recorded 1999 - 2009

Source:

(http://www.bnpb.go.id/website/index.php?option=com_conte nt\&task=view\&id $=2101$

http://dibi.bnpb.go.id/DesInventar/statistics.jsp)

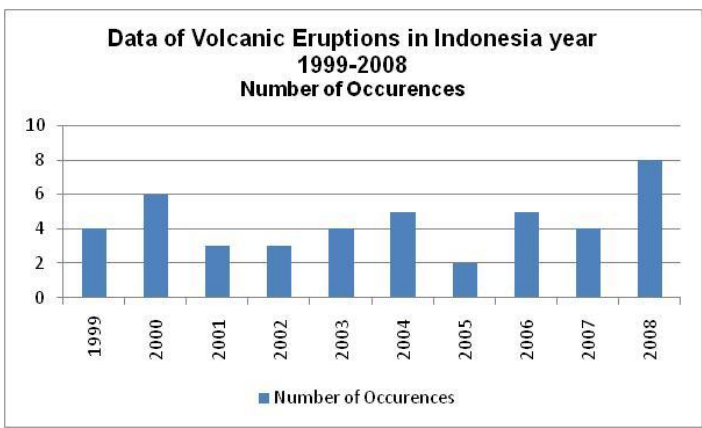

Figure 3. Increase of Volcanic Eruptions recorded 1999 - 2008

Source:

(http://www.bnpb.go.id/website/index.php?option=com_conte nt\&task=view\&id=2101

http://dibi.bnpb.go.id/DesInventar/statistics.jsp)

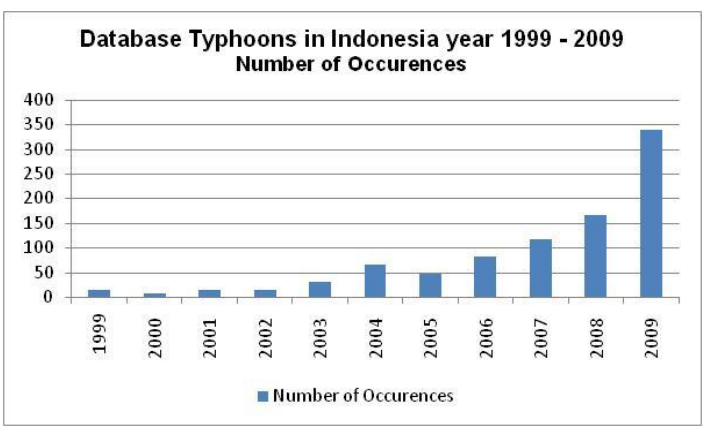

Figure 5. Increase of Typhoons recorded $1999-2009$

Source:

(http://www.bnpb.go.id/website/index.php?option=com_conte nt\&task=view\&id $=2101$

http://dibi.bnpb.go.id/DesInventar/statistics.jsp)

Eventually, the increasing environmental challenges concerned the human sustainability. And the Sustainable Architectural Design Strategy in Indonesia was needed, exceeding the conventional Green Building Guides.

Sustainable Architectural Design could be defined as "the architectural design that delivered with environmental - friendly approach in conscious framework of sustainability. Its design carried out with minimising the negative environmental impact of buildings by enhancing efficiency and moderation in the use of materials, energy, and development space." (http://en.wikipedia.org/wiki/Sustainable architecture). And it was related to the concept of "Sustainable Development" by World Commission on Environment and Development as "the development that fulfilled the current generation needs without compromising the future generation ability to fulfil their needs" (WCED Report of 1987).

Sustainable Architectural Design could be redefined as architectural design that capture the macro - mezzo - micro understanding of the location and utilise low cost, 
low technology and low negative impact solutions for ensuring the human sustainability. The design also should consider the environmental, social as well as economy sustainability of the greater communities not only the clients.

International Union of Architect (UIA) presented an important concept of Sustainable Architectural Design on 7th December 2009 in Copenhagen. It stated its commitment for implementing "Sustainable by Design Strategy" such as:

- Sustainable by Design should begin with the earliest stages of a project and needed commitments between all the stakeholders: clients, designers, engineers, authorities, contractors, owners, users and the community.

- Sustainable by Design needed to incorporate all aspects of construction and future use based on full Life Cycle Analysis and Management

- Sustainable by Design could optimise efficiency through design. Renewable energies, high performance and environmentally benign technologies could be integrated to the greatest practical extent in the project conception.

- Sustainable by Design recognised that all architecture and planning projects were part of a complex interactive system, linked to their wider natural surroundings, and reflect the heritage, culture, and social values of the daily life of the community.

- Sustainable by Design would seek healthy materials for healthy buildings, ecologically and socially respectful land-use, and an aesthetic sensitivity that inspires, affirms and ennobles.

- Sustainable by Design aimed to significantly reduce carbon imprints, hazardous materials and technologies and all other adverse human effects of the built environment on the natural environment.

- Sustainable by Design endeavoured improving the quality of life, promoting equity both locally and globally, advancing economic well-being and providing opportunities for community engagement and empowerment.

- Sustainable by Design recognised the local and planetary interdependence of all people. It acknowledged that urban populations depend on an integrated, interdependent, and sustainable rural-urban system for their life support systems (clean water and air, food, shelter, work, education, health, cultural opportunity, and the like).

- Sustainable by Design endorsed UNESCO's statement that cultural diversity, as a source of exchange, innovation and creativity, was very important for humankind.

In conclusion, each Country's Sustainable Architectural Design Strategy was needed in consideration of the socio-economic and environmental context. Starting with this, the framework of Sustainable Architectural Design in Indonesia was prescribed.

Several Green Building Codes were evaluated to recommend the contextual Sustainable Architectural Design Strategy in Indonesia. These codes were: Leadership in Energy and Environmental Design (LEED) - US Green Building Council USA; Green Mark - Singapore; Green Neighbourhoods Planning and Design Guidelines - Center for Housing Innovation, University of Oregon, USA; High Performance Building Guidelines City of New York, Department of Design \& Construction, USA; and The Land Code, Guidelines for Environmentally Sustainable Land Development - Yale School of Forestry 
\& Environmental Studies, Yale University, USA. And some of the parameters were adopted in the recommendations.

Further, potential environmental challenges such as earthquakes, volcanic eruptions, floods, landslides, tidal waves, and typhoon needed to be mitigated. Some Indonesian National Standard (Standar Nasional Indonesia/ SNI) that prescribed several safety measures were evaluated and integrated into the Sustainable Architectural Design Strategy in Indonesia such as:

- Structural Safety

- SNI 03-1727-1989 - Procedure of Load Design for Houses and Buildings,

- SNI 03-1729-2002 - Procedure of Steel Buildings Design,

- SNI 03-1734-1989 - Procedure of Reinforced Concrete and Reinforced Retaining Wall for Houses' and Buildings' Design,

- SNI 03-2847-1992 - Structural Calculation Procedure of Concrete Structures in Buildings,

- Earthquakes \& Tsunamis Safety

○ SNI 03-1726-2002 Procedure of Earthquake Safety for Houses' and Buildings' Design,

- Floods and Landslides Safety

- SNI 03-1962-1990 Procedures of Planning for Landslides Prevention,

- Extreme Weathers Safety

- SNI 03-2397-1991 - Procedure of Wind-Resistant Houses Design,

- SNI 03-6652-2002 - Procedure of Buildings' Lightning Protection Design,

○ SNI 03-7015-2004 - Lightning' Protection System for Buildings,

- Fires Safety

○ SNI 03-1735-2000 - Procedures of Buildings' and Neighbourhoods' Fire Safety Accesses Planning,

- SNI 03-1736-2000 - Procedure of Houses' and Buildings' Fire Safety Design,

○ SNI 03-1745-2000 - Installation Procedures of Houses' and Buildings' Hydrant System,

- SNI 03-1746-2000 - Procedure of Buildings' Fire Escape Routes Planning.

\section{Methodology}

The research was conducted with evaluating the Sustainable by Design recommendation by UIA and several Green Building Codes. Further existing Indonesian National Standard were evaluated. Later on, discussions were made internally in Petra Christian University acknowledging this issue and prescribing more integrated framework. Last but not least, a study case was examined. The case study selected was a home designed by Dr. Heinz Frick. The case was hopefully able to show sustainable design. 


\section{Results and Discussions}

\subsection{Sustainable Architectural Design Strategy for Indonesia}

The Sustainable Architectural Design Strategy in Indonesia should encompass the following aspects:

Table 1: The Sustainable Architectural Design Strategies for Indonesia

\begin{tabular}{|c|c|c|c|}
\hline General Aspects & Primary Aspects & Sub-Aspects & Strategies \\
\hline \multirow{7}{*}{$\begin{array}{l}\text { The Economical } \\
\text { Aspects }\end{array}$} & $\begin{array}{l}\text { Improving } \\
\text { Quality of Live } \\
\text { (especially Local } \\
\text { Poor) } \\
\end{array}$ & & $\begin{array}{l}\text { Provide employment for local workmen and } \\
\text { utilising local material/ recycled material }\end{array}$ \\
\hline & Functionality & & Provide optimal function of the building \\
\hline & $\begin{array}{l}\text { Cost } \\
\text { Effectiveness \& } \\
\text { Efficiency } \\
\end{array}$ & & $\begin{array}{l}\text { Utilise cost-effective structures and efficient } \\
\text { building materials and finishing }\end{array}$ \\
\hline & $\begin{array}{l}\text { Integrated Design } \\
\text { - Construction - } \\
\text { Management } \\
\text { Process } \\
\end{array}$ & & $\begin{array}{l}\text { Provide integrated approach in design, } \\
\text { construction and building management with } \\
\text { optimum number of building experts }\end{array}$ \\
\hline & Security & & Provide optimum security measures \\
\hline & Safety & $\begin{array}{l}\text { - Structural Safety } \\
\text { - Earthquakes \& Tsunamis } \\
\text { Safety } \\
\text { - Floods and Landslides } \\
\text { Safety } \\
\text { - Extreme Weathers Safety } \\
\text { - Fires Safety }\end{array}$ & $\begin{array}{l}\text { Provide cost effective measures to ensure the } \\
\text { safety of the building users }\end{array}$ \\
\hline & $\begin{array}{l}\text { Future } \\
\text { Adaptability }\end{array}$ & & Provide possible adaptation for building uses \\
\hline \multirow{6}{*}{$\begin{array}{l}\text { The Social } \\
\text { Aspects }\end{array}$} & $\begin{array}{l}\text { People } \\
\text { Awareness for } \\
\text { Sustainable } \\
\text { Design }\end{array}$ & & $\begin{array}{l}\text { Provide campaign to increase the people } \\
\text { awareness for sustainable building design } \\
\text { and building uses }\end{array}$ \\
\hline & Legal Protection & & $\begin{array}{l}\text { Provide strong legal status for building such } \\
\text { as land certification and building } \\
\text { construction permit }\end{array}$ \\
\hline & $\begin{array}{l}\text { Participatory } \\
\text { Design Process } \\
\text { involving all } \\
\text { stakeholders } \\
\end{array}$ & & $\begin{array}{l}\text { Facilitate possible optimum participation of } \\
\text { numbers of stakeholders }\end{array}$ \\
\hline & Aesthetics & & Increase aesthetics for the design \\
\hline & $\begin{array}{l}\text { Cultural Diversity } \\
\text { Preservation }\end{array}$ & & $\begin{array}{l}\text { Facilitate possible cultural diversity of the } \\
\text { users in private buildings }\end{array}$ \\
\hline & $\begin{array}{l}\text { Social } \\
\text { Inclusiveness }\end{array}$ & $\begin{array}{l}\text { - Facilitating Social } \\
\text { Interaction } \\
\text { - Universal Accessibility } \\
\end{array}$ & $\begin{array}{l}\text { Facilitate social interaction and increase } \\
\text { accessibility for all }\end{array}$ \\
\hline \multirow{2}{*}{$\begin{array}{l}\text { The } \\
\text { Environmental } \\
\text { Aspects }\end{array}$} & $\begin{array}{l}\text { Appreciation of } \\
\text { Interrelation- } \\
\text { ships with the } \\
\text { Environment }\end{array}$ & $\begin{array}{l}\text { - Location Selection } \\
\text { - Micro-climate } \\
\text { - Site Planning and Design } \\
\text { - Environmental Impact } \\
\text { Assessment } \\
\end{array}$ & $\begin{array}{l}\text { Appreciate the sites, climates and the local } \\
\text { and global environment }\end{array}$ \\
\hline & $\begin{array}{l}\text { Full Life Cycle } \\
\text { Analysis and } \\
\text { Management }\end{array}$ & $\begin{array}{l}\text { - Thermal Comfort } \\
\text { - Building Materials } \\
\text { - Water Efficiency } \\
\text { - Energy Efficiency } \\
\text { - Waste Management }\end{array}$ & $\begin{array}{l}\text { Utilise the low cost and low technology with } \\
\text { low negative impact in building technology } \\
\text { measures }\end{array}$ \\
\hline
\end{tabular}


Two aspects above were crucial. Improving Quality of Live (especially Local Poor) was the main issue in Indonesia context. One example of strategy was implemented by Mangunwijaya (1998) with the local unique design and recycled materials and built by the local builders. Therefore, he supported the local economy with sustainable construction methods. This strategy was found essential for Indonesia.

Cost Effectiveness \& Efficiency was also the important aspect stated by Vitruvius (www.scribd.com). Vitruvius stated, "Economy denotes the proper management of materials and of site, as well as a thrifty balancing of cost and common sense in the construction of works." Cost efficiency became the main concern of the developments causing the buildings less safe from earthquakes, floods landslides, etc. Therefore, costeffective measures were needed for ensuring the building safety while reducing the unnecessary finishing. Some Indonesian architects implementing the strategy were Eko Prawoto and Adi Purnomo (Akmal, I., 2005).

\subsection{Sustainable Architectural Design Strategy in Heinz Frick House Semarang}

Several aspects in the Strategy were evaluated in the Heinz Frick's house in Semarang, Indonesia. Three main aspects discussed were the Functionality, Cultural Diversity Preservation, Safety and Full Life Cycle Analysis and Management of Heinz Frick House. Other aspects were still analysed in the on-going research.

Firstly, The Heinz Frick House was found very functional and honouring the local cultural. The building is located in the Semarang, Indonesia within the Javanese and Muslim community. Adopting the local Javanese house organisation, the house was designed facilitating social interaction, living, eating, reading and cooking. On the other hand, the kitchen was located in the front part of the house for more defensible space or for security feature.

Secondly, Heinz Frick home is located in the steep highland areas of Ngemplak of Central Java. And it was designed using cost-effective structure system and building material and considering the earthquake and landslide threats. Therefore, concrete foundation with special tar asphalt mixture was used for extra mitigation. The house was built in the split-level avoiding major cut and fill.

Further, the Full Life Cycle Analysis and Management were also taken care. The high humidity (80-90\%) of the site was responded with proper cross ventilation. This caused lower energy consumption. Further, innovative rainwater collection (a 12,000litre cistern) was utilised. It actually provided water for washing, cleaning and irrigation. Waste separation container and composter were also introduced for supporting the gardening activity. Sustainable paints and adhesives were used. Greeneries were also found in many building parts vertically and horizontally. All these shown that low cost, low technology, low negative impact solutions were possible for Indonesia condition.

In the SENVAR 2011, many inputs were given and they are integrated in the paper. The Dr. Heinz Frick's House could be studied further on the aspect of thermal comfort and energy saving. This further would ensure the sustainability of the house. Additionally, the idyllic house setting in the highland was found as the key point of the sustainable home, especially in the thermal comfort aspect. 


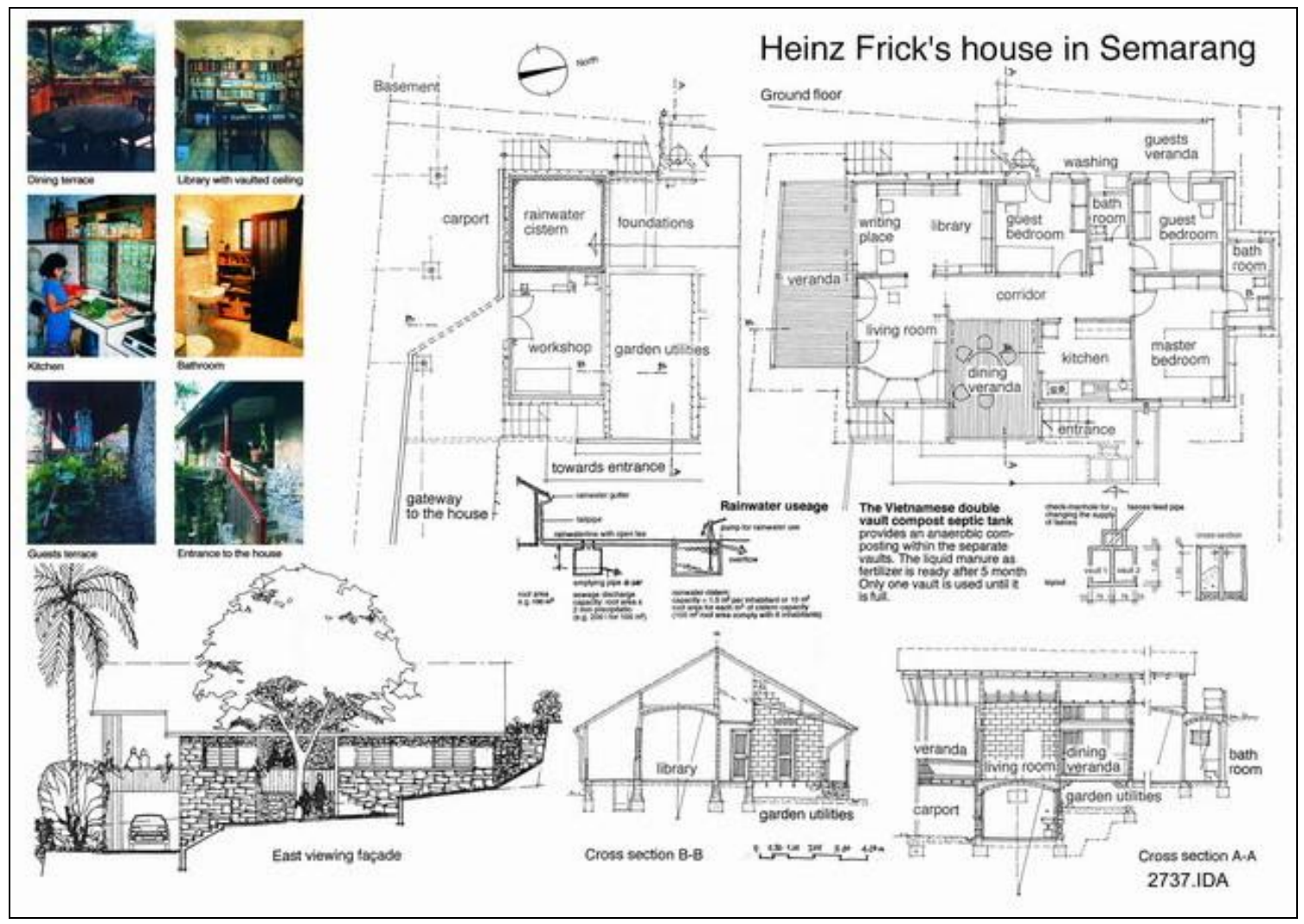

Figure 6. Heinz Frick House Semarang

Source: (http://archnet.org/library/images/one-image-large.jsp?location_id=11714\&image_id=99937)
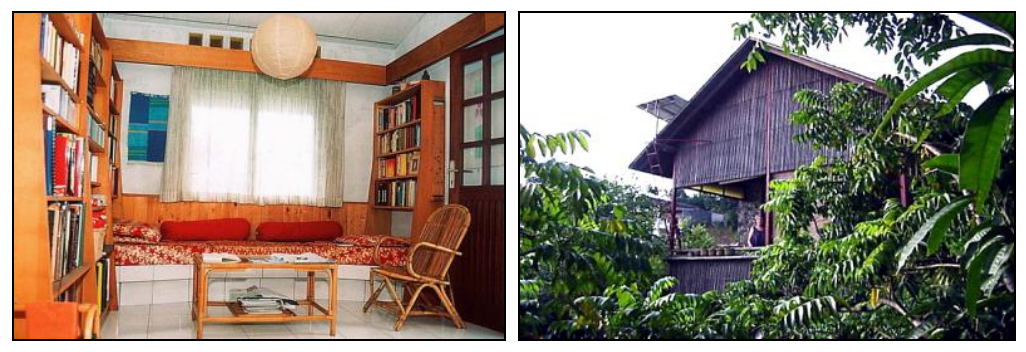

Figure 7. Heinz Frick House Semarang

Source: (http://archnet.org/library/images/one-image-large.jsp?location_id=11714\&image_id=99937)

\section{Conclusion}

The Sustainable Architectural Design Strategy needed to be implemented in Indonesia with consideration of Environmental Challenges as well as Socio-Economic context. The Low Cost, Low Technology and Low Negative Impact Design Strategies could be adopted successfully as implemented in Heinz Frick House in Semarang. Furthermore, site selection and integrated design were found as the key success points of the Sustainable Home. 


\section{Acknowledgement}

We are grateful for the parties that had contributed guidance and knowledge during the writing process of the paper, as mentioned below:

- Architecture Department of Petra Christian University

○ Agus Dwi Hariyanto, ST., M.Sc. Head of Architecture Department.

○ Ir. Joyce M. Laurens, M.Arch., Lecturer of Architecture Department.

- School of Architecture, Planning and Policy, ITB.

- Dr. Ir. Woerjantari Soedarsono M.T., Vice Dean of School of Architecture, Planning and Policy.

- Ir. Eko Purwono MSAS., Lecturer of Architecture Department.

- Dr. Ir. Suryamanto MT., Lecturer of Architecture Department.

- Dr. Ir. Budi Faisal, MLA, MAUD., Lecturer of Architecture Department.

- Dr.Ing. (Cand.) Andry Widyowijatnoko, ST., MT., Lecturer of Architecture Department.

- Ir. Dodo Juliman, Expert of Community Development and Human Settlement Development.

- Ir. Joyce Martha Widjaya MSc., Principal Researcher of Center of Social, Economic and Environment, Public Works Department, Indonesia.

- Mustakim ST., Staff of DKI Jakarta Province Planning Agency.

\section{References}

Akmal, I., (2005), Indonesian Architecture Now, Borneo Publishing

Deasy, C.M., (1990), Designing Places for People: "A Handbook on Human Behavior for Architects, Designers and Facility Managers", PublisherWatson-Guptill.

FAO Global Forest Resources Assessment 2005, http://archnet.org/library/sites/one-site.jsp?site_id=9723

http://as.wiley.com/WileyCDA/WileyTitle/productCd-0470049847,descCdauthorInfo.html

http://cms01.unesco.org/fileadmin/MULTIMEDIA/HQ/CLT/CLT/pdf/Projet_compte_r endu_detaille_3_ORD_IGC_en_final.pdf

http://dibi.bnpb.go.id/DesInventar/statistics.jsp

http://en.wikipedia.org/wiki/Sustainable_architecture

http://environment.yale.edu/topics/ecology_ecosystems_and_biodiversity/962

http://geospasial.bnpb.go.id/category/peta-tematik/statistik-bencana/

http://infibeam.com/Books/info/Jerry-Yudelson/Green-Building-Greensource-Books-

Green-Source/0071546014.html

http://kanisiusmedia.com/pdf/frick-earthquake.pdf

http://portal.unesco.org/culture/en/ev.php-

URL_ID $=35015 \&$ URL_DO=DO_TOPIC\&URL_SECTION $=201 . \mathrm{html}$

http://portal.unesco.org/en/ev.php-

URL_ID $=17716 \&$ URL_DO=DO_TOPIC\&URL_SECTION $=201 . \mathrm{html}$

http://rwienuniverse.blogspot.com/2009/07/energy-expert.html 
http://siteresources.worldbank.org/INTINDONESIA/Resources/Publication/280016-

1152870963030/2753486-1165385030085/Overview_standalone_en.pdf.

http://unesdoc.unesco.org/images/0012/001271/127160m.pdf

http://www.bca.gov.sg/GreenMark/green_mark_buildings.html

http://www.bnpb.go.id/website/index.php?option=com_content\&task=view\&id=2101

http://www.fema.gov/hazard/types.shtm

http://www.fsrd.itb.ac.id/en/wp-

content/uploads/2007/12/THE\%20APPLIED\%20STUDY\%200F\%20ECO.pdf

http://www.indonesiadesign.com/v2/top.php?resolve=4\&edition=060035\&main=6

http://www.indonesianforest.com/;

http://www.nyc.gov/html/ddc/html/design/sustainable_home.shtml

http://www.profauna.or.id/ indo/Fakta_satwa.html;

http://www.pu.go.id/publik/ind/produk/index.asp?Site_id=10403

http://www.sdnpbd.org/sdi/international_days/wed/2005/document/green\%20neig

hborhoods\%20-\%20planning\%20and\%20design\%20guidelines.pdf

http://www.thejakartapost.com/news/2008/06/27/how-build-a-healthy-inexpensivehome.html

http://www.uia-

architectes.org/image/PDF/COP15/COP15_Declaration_EN.pdfhttp://www.uia-

architectes.org/image/PDF/COP15/COP15_Declaration_EN.pdf

http://www.uia-architectes.org/texte/england/Menu-7/3-bibliotheque.html

http://www.unesco.org/culture/ich/index.php

http://www.unesco.org/new/en/unesco/themes/2005-convention/

http://www.usgbc.org/

Mangunwijaya,Y.B., (1998), Wastu Citra, Buku Arsitektur.

Miller, G.T. (2003), Environmental Science, Working With Earth, 10th edition, Brooks/Cole Thomson Learning USA, $\mathrm{p} 1$

Vitruvius quoted in Morgan, M. H., Vitruvius, The Ten Books of Architecture, Harvard University Press, downloaded from: www.scribd.com

WCED, (1987). Our Common Future: Report of the World Commission on Environment and Development, Chapter 2, Towards Sustainable Development, sumber: www.undocuments.net

World Bank (2006). "Making the New Indonesia Work for the Poor - Overview" (PDF). Press release.

World Resources Institute, Forest Frontiers Initiative, WWF-Indonesia \&Telapak Indonesia Foundation (2000), Trial by Fire, Forest Fires and Forestry Policy in Indonesia's Era of Crisis and Reform.

World Resources Institute, Forest Watch Indonesia, Global Forest Watch (2002) , State of the Forest Indonesia.

www.access-board.gov/

www.miusa.org/ncde/tools/universaldesign 